\title{
Controls on oceanic crustal and upper mantle structure by syn and post-accretion processes from multichannel seismic data around and across the Hawaiian-Emperor Seamount Chain
}

D. J. SHILLINGTON ${ }^{1}$, B. BOSTON ${ }^{2}$, R. DUNN ${ }^{3}$, A. B. WATTS ${ }^{4}$, I. GREVEMEYER ${ }^{5}$, L. GÓMEZ DE LA PEÑA ${ }^{5}$, G. ITO $^{3}$, P. WESSEL ${ }^{3}$, U. TEN BRINK $^{6}, \mathrm{~N}$. MILLER $^{6}$, P. CILLI ${ }^{4}$,

'Northern Arizona University, School of Earth and Sustainability, 624 S. Knoles Drive, Flagstaff, AZ 86011 , USA (*correspondence: Donna.Shillington@nau.edu)

'Lamont-Doherty Earth Observatory of Columbia University, 61 Route 9W, Palisades, NY 10964, USA

University of Hawaii, Department of Earth Sciences, 1680

East-West Rd., Honolulu, HI 96822, USA

University of Oxford, Department of Earth Sciences, South

Parks Road, Oxford OX13AN, UK

${ }^{5}$ GEOMAR Helmholtz Centre for Ocean Research Kiel, Kiel, Germany

US Geological Survey, 384 Woods Hole Road, Woods Hole, MA 02543, USA

Very few constraints exist on the structure and evolution of old oceanic crust due to a paucity of observations. Existing sparse seismic reflection data from old oceanic crust in the Pacific and Atlantic Oceans reveal diverse attributes of the oceanic crust and upper mantle, including variable crustal thickness, Moho reflectivity, and intracrustal features. To what extent does this heterogeneity reflect variations in processes during accretion at the mid-ocean ridge or modification by post-accretion magmatism? Here we present a series of long seismic reflection profiles around and across the Hawaiian-Emperor Seamount Chain, which can be used to address this question. Multichannel seismic reflection data were acquired around and across the Hawaiian Chain in 2018. In 2019, comparable seismic reflection data were acquired around and across the Emperor. Oceanic lithosphere in both study areas is Cretaceous in age. Seismic data from both cruises were collected with the $15-\mathrm{km}$-long streamer and $6600 \mathrm{cu}$ in tuned airgun array of the R/V Marcus $G$. Langseth. We observe substantial variations in Moho reflectivity, crustal thickness and internal crustal structure within and between these two study areas. In this presentation, we examine how the attributes of oceanic crust in new seismic reflection data vary with proximity to the volcano chain and other volcanic fields, fracture zones, and other known seafloor features to better understand the contributions of accretion and post-accretion processes in controlling oceanic crustal character. 